\title{
Decolonising Multilingualism in Africa
}




\section{CRITICAL LANGUAGE AND LITERACY STUDIES}

Series Editors: Professor Alastair Pennycook (University of Technology, Sydney, Australia) and Professor Brian Morgan (Glendon College/York University, Toronto, Canada) and Professor Ryuko Kubota (University of British Columbia, Vancouver, Canada)

Critical Language and Literacy Studies is an international series that encourages monographs directly addressing issues of power (its flows, inequities, distributions, trajectories) in a variety of language- and literacy-related realms. The aim with this series is twofold: (1) to cultivate scholarship that openly engages with social, political, and historical dimensions in language and literacy studies, and (2) to widen disciplinary horizons by encouraging new work on topics that have received little focus (see below for partial list of subject areas) and that use innovative theoretical frameworks.

All books in this series are externally peer-reviewed.

Full details of all the books in this series and of all our other publications can be found on http:// www.multilingual-matters.com, or by writing to Multilingual Matters, St Nicholas House, 31-34 High Street, Bristol BS1 2AW, UK.

\section{Other books in the series}

Hybrid Identities and Adolescent Girls: Being 'Half' in Japan

Laurel D. Kamada

Decolonizing Literacy: Mexican Lives in the Era of Global Capitalism

Gregorio Hernandez-Zamora

Contending with Globalization in World Englishes

Mukul Saxena and Tope Omoniyi (eds)

ELT, Gender and International Development: Myths of Progress in a Neocolonial World Roslyn Appleby

Examining Education, Media, and Dialogue under Occupation: The Case of Palestine and Israel Ilham Nasser, Lawrence N. Berlin and Shelley Wong (eds)

The Struggle for Legitimacy: Indigenized Englishes in Settler Schools Andrea Sterzuk

Style, Identity and Literacy: English in Singapore

Christopher Stroud and Lionel Wee

Language and Mobility: Unexpected Places

Alastair Pennycook

Talk, Text and Technology: Literacy and Social Practice in a Remote Indigenous Community Inge Kral

Language Learning, Gender and Desire: Japanese Women on the Move

Kimie Takahashi

English and Development: Policy, Pedagogy and Globalization

Elizabeth J. Erling and Philip Seargeant (eds)

Ethnography, Superdiversity and Linguistic Landscapes: Chronicles of Complexity

Jan Blommaert

Power and Meaning Making in an EAP Classroom: Engaging with the Everyday

Christian W. Chun

Local Languaging, Literacy and Multilingualism in a West African Society

Kasper Juffermans

English Teaching and Evangelical Mission: The Case of Lighthouse School

Bill Johnston

Race and Ethnicity in English Language Teaching

Christopher Joseph Jenks

Language, Education and Neoliberalism: Critical Studies in Sociolinguistics

Mi-Cha Flubacher and Alfonso Del Percio (eds) 


\section{Decolonising \\ Multilingualism \\ in Africa}

Recentering Silenced Voices

from the Global South

\section{Finex Ndhlovu and Leketi Makalela}


DOI https://doi.org/10.21832/NDHLOV3354

Library of Congress Cataloging in Publication Data

A catalog record for this book is available from the Library of Congress.

Names: Ndhlovu, Finex, author. | Makalela, Leketi, author.

Title: Decolonising Multilingualism in Africa: Recentering Silenced Voices from the Global South/Finex Ndhlovu and Leketi Makalela.

Description: Bristol, UK; Blue Ridge Summit, PA: Multilingual Matters, 2021. | Series: Critical Language and Literacy Studies: 26 | Includes bibliographical references and index. | Summary: “This book interrogates and problematises African multilingualism as it is currently understood in language education and research. It challenges the enduring colonial matrices of power hidden within mainstream conceptions of multilingualism that have been propagated in the Global North and then exported to the Global South" - Provided by publisher.

Identifiers: LCCN 2021011127 (print) | LCCN 2021011128 (ebook) | ISBN 9781788923347 (paperback) | ISBN 9781788923354 (hardback) | ISBN 9781788923361 (pdf) | ISBN 9781788923378 (epub) | ISBN 9781788923385 (kindle edition)

Subjects: LCSH: Multilingualism-Africa. | Language policy-Africa. | Decolonization-Africa.

Classification: LCC P115.5.A35 N37 2021 (print) | LCC P115.5.A35 (ebook) | DDC 306.446096- dc23

LC record available at https://lccn.loc.gov/2021011127

LC ebook record available at https://lccn.loc.gov/2021011128

British Library Cataloguing in Publication Data

A catalogue entry for this book is available from the British Library.

ISBN-13: 978-1-78892-335-4 (hbk)

ISBN-13: 978-1-78892-334-7 (pbk)

\section{Multilingual Matters}

UK: St Nicholas House, 31-34 High Street, Bristol BS1 2AW, UK.

USA: NBN, Blue Ridge Summit, PA, USA.

Website: www.multilingual-matters.com

Twitter: Multi_Ling_Mat

Facebook: https://www.facebook.com/multilingualmatters

Blog: www.channelviewpublications.wordpress.com

Copyright (C) 2021 Finex Ndhlovu and Leketi Makalela.

All rights reserved. No part of this work may be reproduced in any form or by any means without permission in writing from the publisher.

The policy of Multilingual Matters/Channel View Publications is to use papers that are natural, renewable and recyclable products, made from wood grown in sustainable forests. In the manufacturing process of our books, and to further support our policy, preference is given to printers that have FSC and PEFC Chain of Custody certification. The FSC and/or PEFC logos will appear on those books where full certification has been granted to the printer concerned.

Typeset by Deanta Global Publishing Services, Chennai, India Printed and bound in the UK by the CPI Books Group Ltd. Printed and bound in the US by NBN. 
Finex - To the memory of my son, Sindiso, for closing all the gaps at home while I was away on project trips that culminated in this book.

Leketi - To my two beloved danghters, Leleti and Koketso, and to all students of multilingualism. 
